\title{
Protection of 316L stainless steel against corrosion by $\mathrm{SiO}_{2}$ coatings
}

\author{
M. ATIK* $\ddagger$ \\ Laboratoire de Chimie de Coordination, Université Cadi Ayyad Faculté des \\ Sciences-Semlalia-Marrakech-Maroc
}

\author{
P. DE LIMA NeTO, L. A. AVACA, M. A. AEgERTER \\ *Instituto de Fisica e Quimica de Sao Carlos, Universidade de Sao Paulo, CP 369 13560-970 Sao Carlos SP, \\ Brazil
}

¥Laboratoire de Science des Matériaux Vitreux, Université de Montpellier II, France

Oxide films prepared by sol-gel methods and presenting high resistance to heat, corrosion, friction and wear, as well as excellent mechanical properties, have recently been developed and put into practical use as structural materials [1-5]. The process of preparation offers potential advantages for modifying the properties of surfaces by low-temperature treatment without altering the original properties of strength and toughness of the substrates. A number of reports on sol-gel coatings concerning the prevention of chemical corrosion and oxidation have been published [6-10]. All of these films increase the protection of metal substrates from air corrosion (tested up to $800^{\circ} \mathrm{C}$ ) and acid attack (tested up to $80^{\circ} \mathrm{C}$ )

The most promising corrosion prevention for stainless steel has been studied by our group using sol-gel films of $\mathrm{ZrO}_{2}, \mathrm{SiO}_{2}, \mathrm{SiO}_{2}-\mathrm{TiO}_{2}$ and $\mathrm{SiO}_{2}$ $\mathrm{Al}_{2} \mathrm{O}_{3}$ prepared by dip-coating using sonocatalysed sols [11-14]. The properties of these coatings have been studied by electrochemical techniques in $\mathrm{NaCl}$ and $\mathrm{H}_{2} \mathrm{SO}_{4}$ solutions. Although preliminary measurements have shown that $\mathrm{SiO}_{2}$ films are not the best protective coatings [13], they provide a very adequate model system to correlate corrosion protection with the physical structure of the sol-gel films.

In this work, amorphous coatings of $\mathrm{SiO}_{2}$ were deposited on 316L stainless steel by the dip-coating technique using a sol preparation involving sonocatalysis. The films were prepared through hydrolysis polymerization of metal alkoxide solutions and conversion to an oxide layer by heating at relatively low temperatures. The effect of the time of heat treatment of the $\mathrm{SiO}_{2}$ films on the corrosion resistance of stainless steel was studied in $15 \% \mathrm{H}_{2} \mathrm{SO}_{4}$ through potentiodynamic polarization curves at $25^{\circ} \mathrm{C}$.

The substrate used in the experiments was $316 \mathrm{~L}$ stainless steel (SS 316L, Caseurop, France) with chemical composition (wt \%): $67.25 \mathrm{Fe}, 18.55 \mathrm{Cr}$, 11.16 Ni, 2.01 Mo, 0.026 Cu, 1.71 Mn and 0.028 C. The specimens were machined into dimensions of $30 \mathrm{~mm} \times 15 \mathrm{~mm} \times 1 \mathrm{~mm}$, degreased ultrasonically in acetone, cleansed by distilled water then dried in air.
For silica films, tetraethylorthosilicate $\mathrm{Si}\left(\mathrm{OC}_{2} \mathrm{H}_{5}\right)_{4}$ (TEOS) was used as the source of silica, absolute ethanol $\left(\mathrm{C}_{2} \mathrm{H}_{5} \mathrm{OH}\right)$ as solvent and glacial acetic acid $\mathrm{CH}_{3} \mathrm{COOH}$ as catalyst. The silica sonosol was prepared by dissolving $\mathrm{Si}\left(\mathrm{OC}_{2} \mathrm{H}_{5}\right)_{4}$ in absolute ethanol to which a small amount of acetic acid $\mathrm{CH}_{3} \mathrm{COOH}$ was added. The volume ratios of $\mathrm{Si}\left(\mathrm{OC}_{2} \mathrm{H}_{5}\right)_{4} / \mathrm{C}_{2} \mathrm{H}_{5} \mathrm{OH}$ and $\mathrm{Si}\left(\mathrm{OC}_{2} \mathrm{H}_{5}\right)_{4} / \mathrm{CH}_{3} \mathrm{COOH}$ were, respectively, 1 and 5 . The mixture was submitted to intense ultrasonic irradiation $(20 \mathrm{kHz})$ produced by a transducer (Heat Systems Ultrasonics W385). After $25 \mathrm{~min}$ the resulting sol was homogenized and remained stable for about five weeks at room temperature when kept in a closed vessel.

Coating films were formed on the substrates by dipping into the clear sonosol and withdrawing at a speed of $10 \mathrm{~cm} \mathrm{~min}^{-1}$. The resulting gel films were dried at $60^{\circ} \mathrm{C}$ for $15 \mathrm{~min}$ and densified in a furnace with air atmosphere by increasing the temperature at a rate of $5^{\circ} \mathrm{C} \mathrm{min}{ }^{-1}$ up to $450^{\circ} \mathrm{C}$ when an isothermal holding of $1 \mathrm{~h}$ was applied in order to remove the organic residues. The temperature was then increased again at the same rate up to either 600 or $800{ }^{\circ} \mathrm{C}$ and maintained at that value for variable lengths of time to complete the densification and obtain adherent coatings. The average thickness of the heat-treated films at $800^{\circ} \mathrm{C}$ was around $0.4 \mu \mathrm{m}$.

$\mathrm{X}$-ray diffraction (XRD) analysis of the substrate and coatings was done with a Philips diffractometer using $\mathrm{Cu} K_{\alpha}$. The diffractogram of SS $316 \mathrm{~L}$ shows the existence of a crystalline phase which corresponds to the cubic phase of the alloy containing $\mathrm{Cr}, \mathrm{Fe}$ and $\mathrm{Ni}$ [4]. When the steel was heated at $800^{\circ} \mathrm{C}$ for $2 \mathrm{~h}$ in air, additional XRD peaks appear corresponding to a mixture of cubic and hexagonal $\mathrm{Cr}_{2} \mathrm{O}_{3}$ [4]. In contrast, samples coated with $\mathrm{SiO}_{2}$ analysed after oxidation tests in air at $800^{\circ} \mathrm{C}$ for $2 \mathrm{~h}$ showed only the peaks of the original substrate, indicating that the silica coating remains amorphous and inhibits any oxidation of the base material.

A Bomem Fourier transformation infrared (FTIR) spectrometer was used to obtain high resolution spectra of the coatings in the $400-4000 \mathrm{~cm}^{-1}$ range; the measurements were carried out at room temperature by reflection at an incident angle of $30^{\circ}$. The spectrum of a coating deposited on SS $316 \mathrm{~L}$ and 
heated at $800^{\circ} \mathrm{C}$ for $2 \mathrm{~h}$ shows bands at 1070,800 and $460 \mathrm{~cm}^{-1}$ corresponding to the different $\mathrm{Si}-\mathrm{O}$ vibration modes [5].

Scanning electron microscopy (SEM; Jeol JSM$6300 \mathrm{~F}$ and Zeiss 960 ) was used to study the nature of the surface of uncoated and coated substrates. Fig. 1a shows the structure of 316L stainless steel surface as received. After heat treatment of the sample for $2 \mathrm{~h}$ in air at $800^{\circ} \mathrm{C}$ small crystals grew at the surface in agreement with the XRD analysis, while after $20 \mathrm{~h}$ the $\mathrm{Cr}_{2} \mathrm{O}_{3}$ crystals were fully developed and covered the whole surface (Fig. 1b). On the other hand, treatments of the bare SS $316 \mathrm{~L}$ at $600^{\circ} \mathrm{C}$ led to surfaces presenting oxide layers of unspecified composition, as illustrated in Fig. 1c for a sample treated for $10 \mathrm{~h}$. In the case of coated samples, the initial treatment for $2 \mathrm{~h}$ at either 600 or $800^{\circ} \mathrm{C}$ resulted in homogeneous layers but with some porosity due to incomplete densification, as shown in Fig. $2 a$ and b. After $10 \mathrm{~h}$ the films were dense and signals of cracking appeared on the surface (Fig. 2c). Finally,
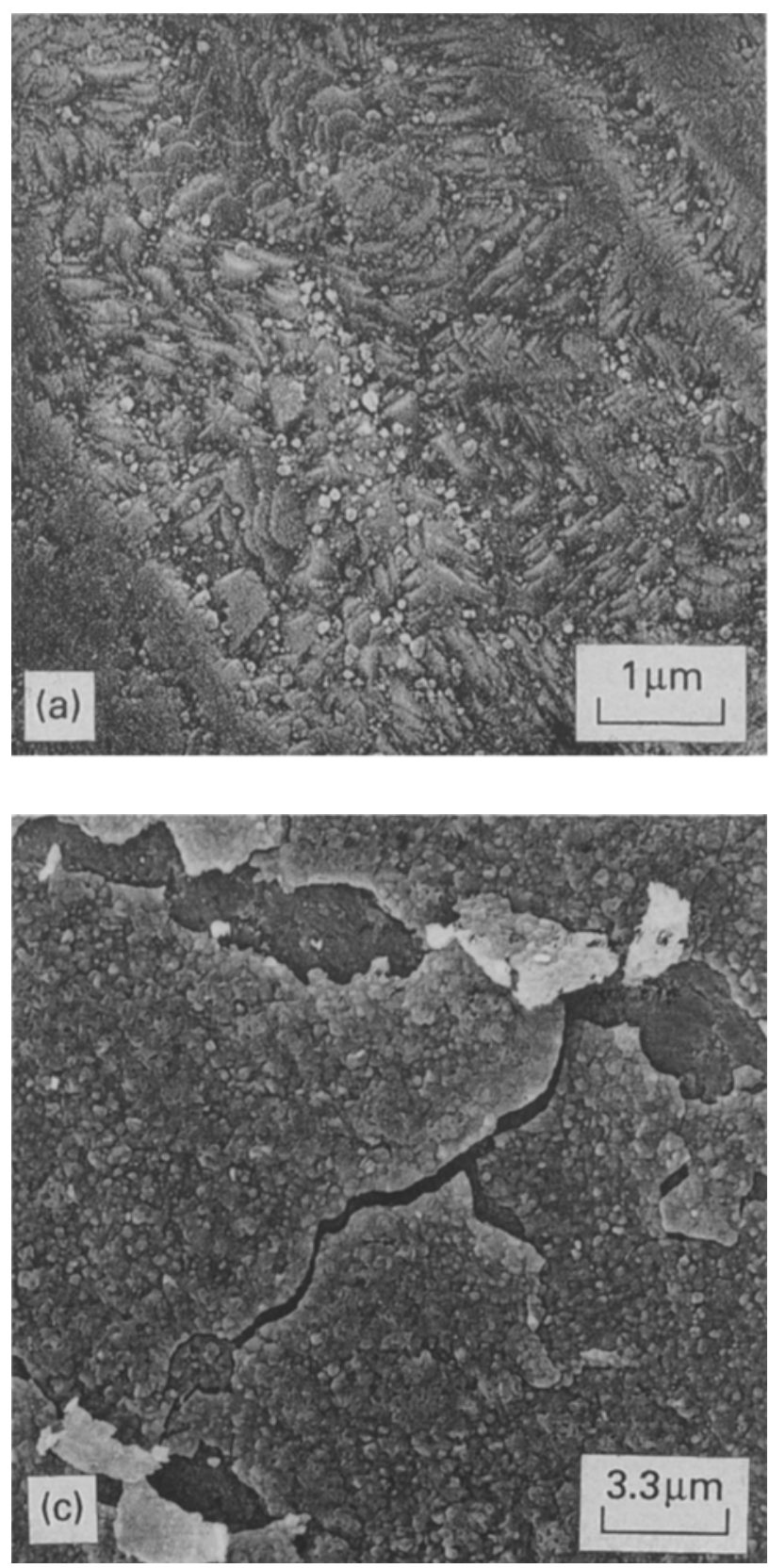

after $20 \mathrm{~h}$ at either temperature the films were extremely dense but showed large cracks where $\mathrm{Cr}_{2} \mathrm{O}_{3}$ crystals were seen, as illustrated in Fig. $2 \mathrm{~d}$ for a treatment at $800^{\circ} \mathrm{C}$. The physical reason for this decohesion is the growth of a layer of $\mathrm{Cr}_{2} \mathrm{O}_{3}$ crystals (also containing $\mathrm{Mn}$ and $\mathrm{Fe}$ ) at the metal-coating interface, causing significant stress in the film and leading eventually to its fracture under prolonged high temperature treatment.

Electrochemical measurements were carried out in order to determine the potentiodynamic behaviour of different samples in deaerated $15 \% \quad \mathrm{H}_{2} \mathrm{SO}_{4}$ (Merck p.a.) aqueous (Milli-Q) solutions at $25^{\circ} \mathrm{C}$ using a computerized PARC 273 potentiostat/galvanostat. A saturated calomel electrode (SCE) was used as reference and a Pt foil served as auxiliary electrode. The working electrodes were $316 \mathrm{~L}$ SS plates, either bare or coated with $\mathrm{SiO}_{2}$ of $0.4 \mu \mathrm{m}$ thickness, immersed $1 \mathrm{~cm}$ in the solution. The samples were subjected to a variety of heat treatments prior to the recording of the curves. The

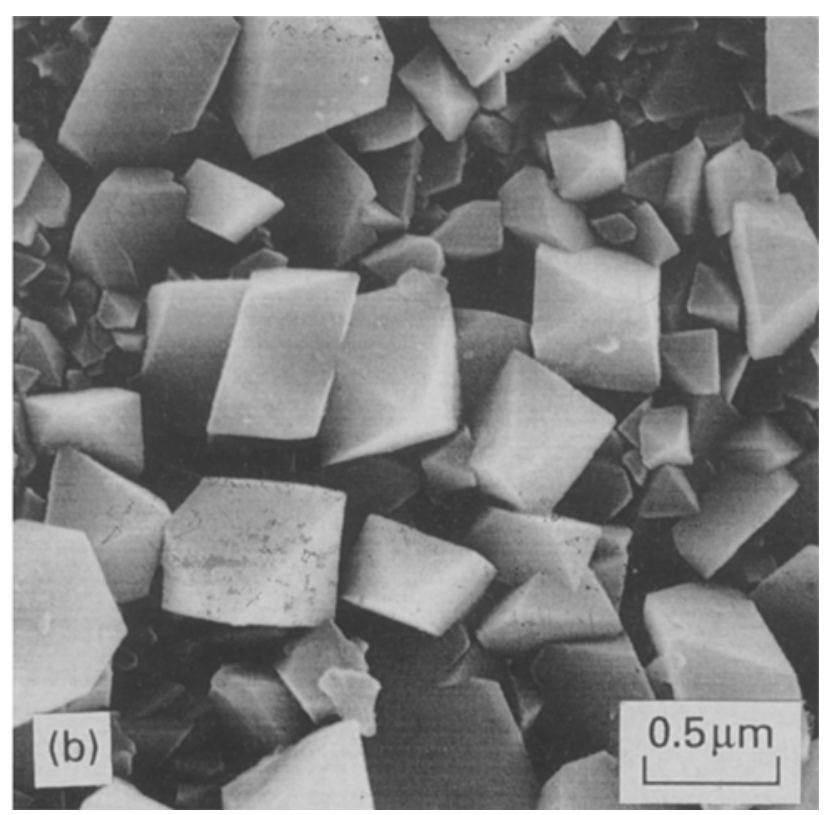

Figure 1 SEM micrographs of the $316 \mathrm{~L}$ stainless steel: (a) as received and after heat treatment for $2 \mathrm{~h}$ at (b) $800^{\circ} \mathrm{C}$ and (c) $600^{\circ} \mathrm{C}$. 

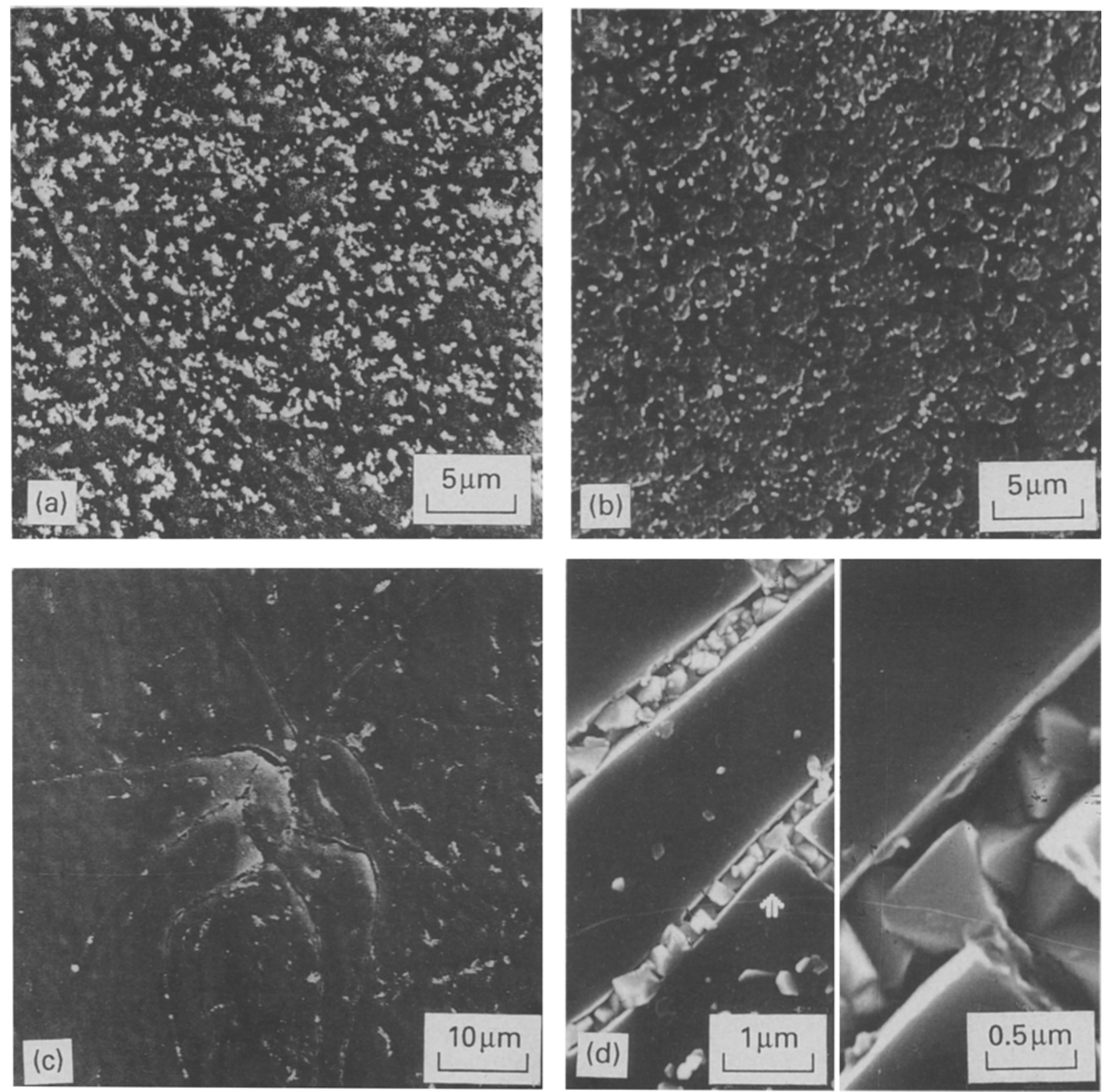

Figure 2 SEM micrographs of samples of $316 \mathrm{~L}$ stainless steel coated with $\mathrm{SiO}_{2}$ and heat-treated at (a) $600{ }^{\circ} \mathrm{C}$ and (b) $800{ }^{\circ} \mathrm{C}$ for $2 \mathrm{~h}$, (c) $600^{\circ} \mathrm{C}$ for $10 \mathrm{~h}$ and $(\mathrm{d}) 800^{\circ} \mathrm{C}$ for $20 \mathrm{~h}$.

potentiodynamic measurements were initiated at $-0.7 \mathrm{~V}$ versus SCE and scanned continuously in the anodic direction at $1 \mathrm{mV} \mathrm{s}^{-1}$. Fig. 3 illustrates the results obtained for the bare substrate as received (curve a) and those for $\mathrm{SiO}_{2}$ coatings heat-treated at $800{ }^{\circ} \mathrm{C}$ for 2 and $10 \mathrm{~h}$ (curves b and c, respectively). Other experiments were also performed and the whole set of data was analysed with the PAR 342 corrosion measurements software, which furnishes several electrochemical parameters of the system under study. Thus, for each sample the corrosion potential, polarization resistance and corrosion current can be recorded. From this last parameter it is possible to calculate the corrosion rate (CR), which measures the amount of material that will be dissolved from the unitary surface in a given length of time. In the present case, CR is quoted in mills per year $\left(1 \mathrm{mpy}=25.410^{-3} \mathrm{~mm} \mathrm{year}^{-1}\right)$.

As shown by the SEM results, the substrate itself is extremely sensitive to different heat treatments. Thus, from the material as received the effect of temperature $(T)$ and time $(t)$ of heat treatment on the corrosion characteristics of different samples was measured. Fig. 4 (curves $\mathrm{a}$ and $\mathrm{b}$ ) shows the variation of $\mathrm{CR}$ with $t$ at 600 and $800{ }^{\circ} \mathrm{C}$, respectively. At the lower temperature, SS $316 \mathrm{~L}$ undergoes a strong sensitization [15] and CR increases dramatically with $t$. This effect is in close correlation with the SEM observations (Fig. 1c). When the treatment is carried out at $800^{\circ} \mathrm{C}$ the sensitization is less pronounced, as expected [15] and little change is observed at the surface, although CR increases considerably (curve $b$ in Fig. 4). In the presence of the $\mathrm{SiO}_{2}$ coatings the behaviour is again different at the two temperatures investigated. For treatments at $600^{\circ} \mathrm{C}$ the coatings protect the surface when the comparison is made with respect to the treated bare substrate (curves $\mathrm{c}$ and a in Fig. 4) but the CR values 


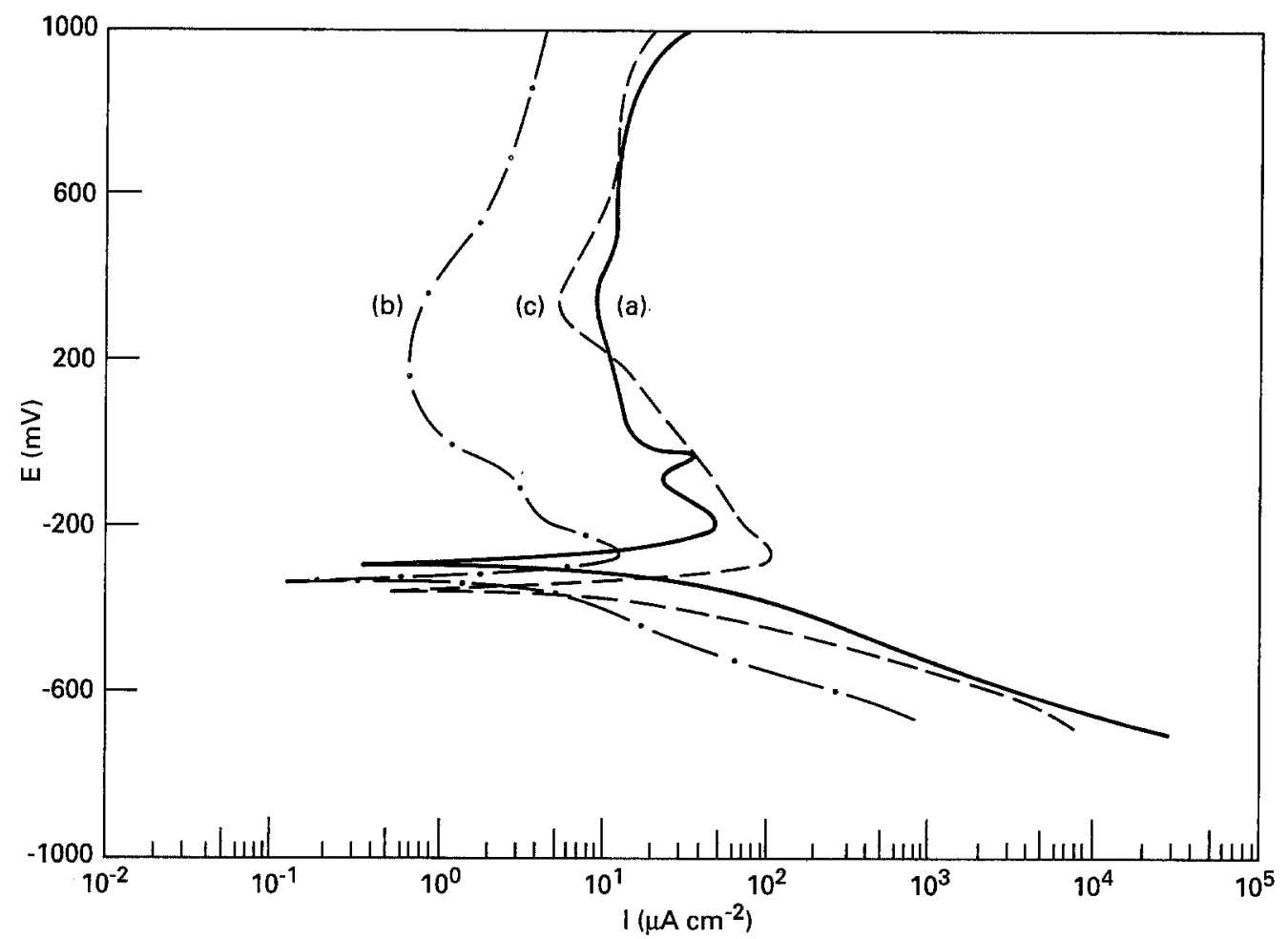

Figure 3 Potentiodynamic polarization curves recorded at $1 \mathrm{mV} \mathrm{s}^{-1}$ in deareated $15 \% \mathrm{H}_{2} \mathrm{SO}_{4}$ aqueous solutions on (a) $316 \mathrm{~L}$ stainless steel as received and on samples coated with $\mathrm{SiO}_{2}$ and heat treated at $800^{\circ} \mathrm{C}$ for (b) $2 \mathrm{~h}$ and (c) $10 \mathrm{~h}$. Potentials referred to SCE.



Figure 4 Variation of the corrosion rate (CR) measured in $15 \%$ $\mathrm{H}_{2} \mathrm{SO}_{4}$ solutions at $25^{\circ} \mathrm{C}$ with the time of heat treatment (in air) for $316 \mathrm{~L}$ stainless steel treated at (a) $600^{\circ} \mathrm{C}$ and (b) $800^{\circ} \mathrm{C}$ and for the same material coated with $\mathrm{SiO}_{2}$ and treated at (c) $600{ }^{\circ} \mathrm{C}$ and (d) $800^{\circ} \mathrm{C}$.

are considerably larger than those of the original material (i.e. the value for $t=0$ ). The SEM images of the coated surfaces under these conditions (Fig. $2 a$ and c) reveal that the film is not totally continuous but still effectively protects the steel against the action of $\mathrm{H}_{2} \mathrm{SO}_{4}$. On the other hand, the results for films treated at $800^{\circ} \mathrm{C}$ are very interesting (curve $d$ in Fig. 4). Firstly, CR is lower and remains well below the value for the bare substrate up to $15 \mathrm{~h}$ of heat treatment. For $t$ close to $20 \mathrm{~h}$, the film cracks as the result of the growing of $\mathrm{Cr}_{2} \mathrm{O}_{3}$ crystallites, as shown in Fig. 1b, and CR increases suddenly. The potentiodynamic curves (Fig. 3) suggest that the coating is acting as a physical barrier $[13,14]$, in particular for the smaller $t$, which is in agreement with the SEM observations reported above.

The behaviour described above is almost identical for other types of films $\left(\mathrm{ZrO}_{2}, \mathrm{TiO}_{2}-\mathrm{SiO}_{2}\right.$ etc. $)$ and illustrate the effects and sequence of events that make these sol-gel coatings so effective for corrosion protection in acid environments. It also serves as a guide for the type of temperature regions in which this kind of stainless steel can be safely utilized when protected by $\mathrm{SiO}_{2}$ coatings.

\section{Acknowledgements}

This research was supported by FAPESP, FINEP, CNPq, CAPES/PICD and the Program RHAE-New Materials (Brazil).

\section{References}

1. S. SAKKA and K. KAMIYA, J. Non-Cryst. Solids 42 (1980) 403.

2. N. TOHGE, A. MATSUdA and T. MINAMI, Chem. Express 2 (1987) 141.

3. O. DE SANCTIS, L. GOMEZ N. PELligri, C. PARODI, A. MARAJOFSKY and A. DURAN, J. NonCryst. Solids 121 (1990) 338. 
4. M. ATIK and M. AEGERTER, ibid. 147/148 (1992) 813.

5. M. ATIK and J. ZARZYCKI, J. Mater. Sci. Lett. in press.

6. M. ATIK and M. A. AEGERTER, in "Better ceramics through chemistry V", edited by M. J. Hampden-Smith, W. G. Klemperer and C. J. Brinker (Materials Research Society, Pittsburg, Pennsylvania, 1992) Vol. 271, p. 471.

7. A. R. DI GIAMPAOLO, M. PUERTO, J. LIRA and N. RUIZ, J. Non-Cryst. Solids, 147/148 (1992) 467.

8. M. GUGLIELMI, D. FESTA, P. INNOCENZI, P. COLOMBO and M. GOBBIN, ibid. 147/148 (1992) 474.

9. K. IZUMI, H. TANAKA, Y. UCHIDA, N. TOHGE and T. MINAMI, ibid. $147 / 148$ (1992) 483.

10. M. ATIK, C. R'KHA and J. ZARZYCKI, J. Mater. Sci. Lett. 13 (1994) 266.

11. P. de LIMA NETO, M. ATIK, L. A. AVACA and M. A.
AEGERTER, J. Sol-Gel Sci. Technol. 1 (1994) 177.

12. M. ATIK, P. de LIMA NETO, M. A. AEGERTER and L. A. AVACA, in Proceedings of the 44th ISE Meeting, Berlin, 1993, p. 11. 3.7, p. 297.

13. P. de LiMA NETO, M. ATIK, L. A. AVACA and M. A. AEGERTER, in Proceedings of the 7th International Workshop on Glasses and Ceramics from Gels, Paris, 1993 (to be published in J. Sol-Gel Sci. Technol.).

14. M. ATIK, P. de LIMA NETO, M. A. AEgERTER and L. A. AVACA, J. Appl. Electro. in press.

15. A. J. SEDRIKS, "Corrosion of stainless steels" (John Wiley, New York, 1979).

Received 21 January

and accepted 18 February 1994 